\title{
Electoral Politics in Pakistan (Elections 2013): A Case Study of District Muzaffar Garh
}

\author{
Fariha Khalid Khan (Corresponding Author) \\ Department of Political Science, \\ The Islamia University of Bahawalpur \\ E.mail: farihakhalidkhan@gmail.com
}

Prof. Dr. Razia Musarrat,

Chairperson, Department of Political Science,

The Islamia University of Bahawalpur

Accepted: December 03, 2014

Doi:10.5296/ jpag.v4i4.6628 URL: http://dx.doi.org/10.5296/ jpag.v4i4.6628

\begin{abstract}
Elections make a fundamental contribution to democratic governance. In democracies political decisions are made directly by the citizens of the country. Elections serve as forum for the discussion of public issues and facilitate the expression of public opinion. Electoral politics is a figurative form of political participation. Success and failure of political institutions depends upon the political awareness of people and the process of electoral politics is the subject of free, fair and transparent elections. Like her counterparts Pakistan has election process defined by constitution. The electoral process in Pakistan was not regular and transparent but last three elections 2002, 2008 and 2013 were held according to the constitution. In Pakistan elections and political process are dominated by the political personalities. Although there are multiparty system but people mostly preferred two main parties like PPP and PML-N but it is positive that third party PTI was emerged in country as third largest party of Pakistan. The study focuses on the 2013 elections and behavior of people of district Muzaffar Garh of Punjab. The purpose of this study is to observe the electoral politics at micro level in Pakistan.
\end{abstract}

Keywords: Elections, Electoral politics, political participation, political institution 


\section{Introduction}

In different parts of the world the individuals choose their political leaders, representatives and governmental authorities through direct and indirect elections. For the growth of democracy and development of the country regular, transparent and free elections play important role. In democracies elections are complex event which affect the total social and political process through individuals and collective decisions. Elections are major agencies for political participation and political socialization. Elections open up networks between individuals and governments and between elite and masses. Elections exhibited the political system, its nature and actual functioning of whole system. (Encyclopedia, 2oo8, p.557)

Electoral politics is figurative form of political participation. Regular and transparent elections are fundamental for effective democracy. The transparent elections reflect the will of the people, which provided the bases for the assurances of government. Henry J. Steiner states, "Countries with markedly different political systems have termed political participation the vital human right. In its absence, it is said; all others fall to a perilous existence." (Sills, 1968, p.2)

Political culture of Pakistan is mixed and complicated because of ethnic and lingual distinctions. The country's democracy derailed through army for four times in the political history of Pakistan. The continuous interventions of army make fragile democracy, authoritative and feudal political culture and lack of national consensus hindered the electoral politics of the country. The irregular conduct of elections affected the political culture and democratic values of the Pakistan. Flawed elections shaped imperfect results. The practices of electoral rigging, lack of transparency, change of results in favorer of incumbent or strong political parties, gerrymandering, misuse of government machinery and media would make elections ineffective, reduced the purity of the electoral process and weaken the faith of public in them. All these are common practices in Pakistan. (Ahmad, 2004, p.46)

From 1970-2013 Pakistan experienced ten general elections. Elections of 1985 were held after eight years of existing elections. The 1988 and 1990 were separated by gap of less than two years. There are only three assemblies which completed their terms in Pakistan. The 1970 Assembly although experienced the tragedy of East Pakistan, (Mujahid, 1971, p.160) it took oath in 1973 and dissolved in 1977. The second Assembly was 2002 Assembly which constitutionally completed its duration. (Election compendium, 2012) 2008 Assembly was the third Assembly that also completed its tenure. Three of ten elections were held under Legal Frame Work Order because at that time there was no existing constitution; it was suspended or abrogated by army generals. Four elections were held president in offices they created suspicious circumstances and dissolved assembly prematurely. In the history of Pakistan all elections were unique and different in characters. The first three 1970, 1977 and 1985 stood out not only for their distinct political significance but they also adopted constitutional process. The country saw four general elections from 1988-1999 in which no Assembly could complete its journey, November 1988, November 1990, October 1993 and February 1997. . (Desai, 2005, pp.136-137)

The 1997 government won two third majority and took measure to annul the amendment 58(2) (b) which imbalance the power position, but the assembly experience the downfall when General Parveez Musharraf after three year of elections captured power. The new era started with Musharraf period when he introduced new reforms in electoral system this includes joint electorate, lower voting age, increased number of women seats and re-demarcated constituencies. Under new electoral system the elections were held in 2002, 2008 and 2013.

The elections of 2013 were held in a time when Pakistan was facing critical phase of its history. The outgoing PPP-led coalition government although completed its five year term but during the period Pakistan become the weaken state of South Asia having corruption, load shading, inflation and terrorism. In these elections the key players were Pakistan People's Party, Pakistan Muslim League(N) and one rising party which competed the both previous 
parties is Pakistan Tehreek-e- Insaf. (Hashmi, May 2013)

The study focuses on the common perception in district Muzaffar Garh. The elections and voting decision are influenced by social factors as biradrism, and family ties, changing voting behavior and domination of two parties. In urban and rural areas of Pakistan different factors influenced the people. The study is confined to district Muzaffar Garh. The purpose of selecting the small district of Punjab is to evaluate the electoral politics at micro level in Pakistan. The reviewed literature on electoral politics and voting trends show that there is difference of opinion between scholars on the factors determining voting behavior of people in Pakistan. Some argued that strong political parties have role, other said it is the role of individuals. Some scholars mentioned the role of socio-economic factors and some highlited the local political structure. The study has a multidimensional approach towards electoral politics.

\section{Literature Review}

On electoral politics and elections many Pakistani scholars have academic research but there are few who generally reserved for study of electoral trends, analysis of constituencies and data collection. The available data on elections is related to the performance of political parties and alliance politics. In order to analyze the electoral politics in Pakistan, the impacts of elections on political system and on economy, we have studied following books, articles and journals related to topic

Dahl (1956) said that democracy is a vague concept of Political Science. It has little relation to the real world but he gave excellent conceptual analysis combined with empirical relevance. According to Dahl theory of democracy has two influential model theories the one is Madisonian, representing the prevailing American doctrine, the populist theory and argues that they no longer explain how modern democracies operate. He then constructs a model more consistent with modern Political Science and develops some unique views of popular sovereignty and the American constitutional system.

Jalal (1969) examined the colonial legacy of subcontinent, the partition, creation of Pakistan and political process in Pakistan and India, their political economy by saying that in contemporary South Asia the democracy is succeeded in India and failed in Pakistan and Bangladesh. Most of the period both experienced authoritarianism. The success of formal democracy of India is a result of strengthen political institutions and by their leaders.

Baxter (1971) gives complete overview of 1970 general election in Pakistan. The 1970 election is initial step for restoration of democracy in country where election held for the first time on the basis of universal suffrage, direct voting and single member constituency of equal sizes. The author gives complete National and Provincial Assemblies results. The 1970 elections were held on the basis of 1961 census report and constituencies were redrawing and delimited on the basis of it.

Palmer (1975) presents the complete analysis of elections and political development in South Asia in the decade of 70s. The book covers the elections of India, Pakistan, Ceylon and Bangladesh and their political systems.

Weinbaum (1977) in his article analyzed 1977 election in Pakistan. Bhutto assumed power in 1971 and dominate electoral politics till 1977. But the 1977 elections were failed to signal a clear victory. Once again the 1977 election demoralized the country when country experienced civil war like condition. Election was rigged and not accepted by PNA and other opposition parties.

Choudhury (1988) explain that Pakistan was established under Indian Independence Act 1947. The electoral process was started in 1892 in subcontinent when Britishers introduced electoral principals and representative institutions. Before the creation of Pakistan many pacts was passed for the rights of Muslim of subcontinent and finally the separation of India was accepted. After the creation of Pakistan three Constituent Assemblies were made for drafting constitution of country. The author also discusses the first martial law, the first general 
election, the Bhutto period, federalism, and judiciary and parliamentary vs. presidential election.

Bukhari explains in his book (1990) all the incidents and events in detail from 1922-1988. The book describes the combination of Islamization and modernization by the insincere leaders those did not allow the democracy to flourish in the country. The result can be extracted in a way that both Islamization and modernization system was not taken as a system, therefore the controversy still exist in Pakistan politics.

Report of SAARC-NGO observer (1995) describes the summary of 1993 National Assembly election and electoral politics in Pakistan. The report gives complete study of democracy, the constitutional and legal framework before election and women and electoral process.

Mueller (1996) analyzed that how the basic constitutional structure affects the government offices. This relationship is important in a time when countries of world around the Soviet Blok re-write there constitution and America is trying to sort out the democratic problems.. The author by comparison of governmental structure of America and other countries of the world illuminate the link between democratic government and its outcomes. The book analyzed electoral and voting rules, federalism, citizenship and separation of powers.

Talbot (1998) examined the historical understanding of Pakistan. Most of the period experienced authoritarianism and reactionary policies of parties, establishment in contrast to democratic India. From its birth Pakistan faced rapid change. The writer answered the question, why democracy succeeded in India while Pakistan has coped with dictatorship.

Dutt (2000) analyzed the inside situation of Pakistan by describing revenge of generals and military intervention in politics, development in Pakistan under different rulers and 1993 election of Pakistan. He said Pakistan is the second largest nation of South Asia it has ideal future if it overcome its challenges.

Mehmood (2000) describes the constitutional history and development of Pakistan. The book answers some important questions such as why Pakistan faced economic and political crisis. Why military and bureaucracy expanded their roles in politics? What are the future prospects of constitutionalism, democracy and stability? The book presents a complete overlook of the making and abolition of different constitutions, performance of political parties, working of military governments and dilemma of democracy. Overall it is a comprehensive book about history, politics and foreign policy of Pakistan.

Thompson (2004) wrote the book in the light of presidential elections 2000 and addressed the fundamental principle of democracy in which three are important that are equal respect, free choice and popular sovereignty. But these principles exist in theory the actual practice is absent. So there is conflict in basic values and practice. The voters are illegible to judge the process of election process and its outcomes. The book compiles the legal, philosophical and political aspects of electoral process, district boundaries registration and voting process.

Khan (2005) a retired army general analyzed that we have learnt nothing from history. His book covers a lot of topics such as sayings of Quaid-e-Azam, the establishment of Bangladesh and rebirth of democracy. It also covered the second general elections, political dialogue, Musharraf period and his Devolution of Power Plan along with Indo-Pak relations and future of democracy in Pakistan. It is a comprehensive study about political system of Pakistan.

Ahmad (2005) examined the return of Benazir Bhutto, the daughter of Zulfikar Ali Bhutto in Pakistan raised hope among people that she would fulfill the promise of his father. Due to military regime, the situation of country was not good. She had shown the courage to handle all the challenges of Pakistan. In this book the writer discussed in detail the situation of country after Zia, new political process of reconciliation the return of Benazir Bhutto and her involvement in Pakistani politics.

Waseem (2006) focused on theoretical aspects of elections in Pakistan during 1993 and 2002. 
This is scholarly work which gives a comprehensive study relating to the role of political parties, election campaign and their results and legislature in the context of 2002 election. It also describe the political trends in Pakistan, voting behavior, civil-military relations, party politics and absence of |charismatic leadership in 2002 elections. The two prominent parties Pakistan People's Party and Pakistan Muslim League (N) were ousted from the scene. The alliance of religious parties Mutahoda Majlis-e-Amal (MMA) was made for the adjustment of Army president. The one good thing was that the women seats were increased in numbers.

Haider (2008) in his book discusses elections of 2008 in detail the pre-election situation of country as the serious security problems, judicial crisis and opposition of political parties against election under uniformed president. The author describe in detail the constituency to constituency election result of National Assembly and provincial assembly, the code of conduct for 2008 election, reserved seats of women and for non-Muslims. The list of major key players of election and their allotted symbols and all aspects of 2008 election are included in the book.

In his article "Pakistani Elections: Troubled Legacy" Rasul Baksh Rais gives a beautiful outlook of Pakistani political culture, the impacts of general elections on Pakistan, electoral malpractices like rigging, gerrymandering, misuse of media and governmental machinery, institutional arrangements etc. The Pakistani people are getting aware by their political system so there is need to reform the electoral system of Pakistan.

"Electoral Politics in Pakistan (1955-1969)" the article is written by Tahir Kamran. He critically analyzed 1950s and 1960s elections and the electoral reforms of the period. He is of the view that people went to the polls many times in the history of Pakistan but they never learned a lesson. It also has been cited the Ayub era, the creation of election commission and its reforms according to first two constitutions.

The Pakistan election compendium was published in 2012 which was compiled by Naqqash and Tariq. It is a complete study of electoral history of Pakistan from British period which provided base for struggle for Pakistan and post-independence electoral history from 1947 to on word. The book especially focused on 1970 to 2008 election. The volume one describes the 1970, 1977 and 1985 elections with detail of national and provincial assemblies of Pakistan. The volume two represents the complete details of elections from 1988 to 2008.

Shawar and Asim (2012) observed in democratic countries voting is major form of political participation and study of voting behavior is sub-field of political science. The authors selected the area of Fasialabad for their research work. They collected data about the voting behavior of people about different political parties through questionnaire. The study showed that the people mostly consider personalities except parties and factor of biradrism capture the voting behavior of people in the respective area.

Bureau of Statistics (2012) gave a complete district, tehsil and town wise study of Punjab development from 1998 to 2011. The report discusses in detail the male/female population ratio, union councils, divisions and districts of Punjab. It provide facts and figures about development of all types of institution of Punjab such as population, districts, divisions, fisheries, agriculture, industries, education, railways, postal and police departments etc. It provides important statistics in respect of social, economic and financial sectors of the economy at aggregate as well as sartorial levels.

PilDat (2013) analyzed the manifestoes of political parties in Pakistan for 2013 election and compare it with 2002 and 2008 electoral manifestoes of parties. Manifestoes are integral part of electoral process. Party manifestoes attract the people towards party. Party manifestoes helped the public for informal decision making of vote casting.

European Union Election Observation Mission (2013) prepared report on general elections 2013 in Pakistan. According to report the electoral process progressed with high level of voter turnout. Pakistan ratified UN covenant on civil and Political Rights and election 2013 held under this treaty. 
Rizvi and Gilani(2013)wrote about ten general elections in Pakistan. The story of ten general elections is full of confusion as the first general election resulted in the division of Pakistan. The second general election transforms power from civil to military. The continuous election from 1985 to 2008 were manipulated by ISI, law and order and security challenges. The elections of 2013 indicate democratic continuity from one civilian government to another.

\section{Research Methodology}

The researchers conducted the mix study as a research design for the purpose to measure the opinions of the population about the particular issue. The researchers used this design to identify the electoral politics in district Muzaffar Garh in the perspective of elections 2013. Mix study is the research design that includes quantitative, descriptive and analytical method for data collection. The data is interpreted in form of tables with discussions. In the present research the purpose of selected population was to evaluate the electoral politics at micro level in the district Muzaffar Garh. For present study 150 respondents in all from male and female were selected for National and Provincial seats from different constituencies of district Muzaffar Garh. To gather data from the targeted population researcher used the simple random sampling. A simple random sampling is obtained by choosing basic units in search a way that each unit in the population has equal chance of being selected. Questionnaire was used in this study for data collection. The study is quantitative in its nature and form. In this study the information was collected through self-administered questionnaires distributed personally to the respondents by the researcher. Finally the observation made by the researcher and responses of the questionnaire were read, tabulated and analysed through SPSS.

\section{i. Muzaffar Garh: A Description}

Muzaffar Garh is one of the oldest districts of Punjab and is the most developed district of the DG Khan division. Nawab Muzaffar Khan, the governor of Multan found it in 1794. It is situated in Southern Punjab at the exact center of Pakistan. Muzaffar Garh is situated between East side of river Chenab and West side of river Indus. District Muzaffar Garh covered the $8,435 \mathrm{~km}$ area of Punjab.

Although agriculture is the backbone of economy, several industrial units, a power plant and an oil refinery are big sources of employment for locals. Cotton Ginning and pressing, jute textile, flour mills, petroleum products, oil mills, sugar mills, power generations, textile composite and spinning, paper articles, readymade garments and poly propylene bags are important industries of district Muzaffar Garh. Muzaffar Garh district has PARCO oil refinery in Qasba Gujarat, it fulfill 35\% of Pakistan's need. In Muzaffar Garh there are three important power plants, Kot Addu power plant KAPCO, Lalpeer thermal power station and Muzaffar Garh thermal power station and the capacity of all these power stations is up to 3300 MW. (1998, District Census Report)

From agriculture side district Muzaffar Garh is rich as cotton, wheat and sugarcane are the main crops. Bajra, jawar, moong, rice, maize and oil seeds i-e sunflower and mustard, mash and masoor grown in minor quantities. Some fruits are also grown in minor quantity such as jaman, dates, pears, bananas and phalsa. The main vegetables of the district are onions, carrots, peas, cauliflowers, turnip, garlic, ladyfinger, chilies, potatoes and tomatoes. (WSIP.2013)

As a large district with 3.56 million populations, estimated in 2010, the district divided into four tehsils which is further divided in 93 union councils and 984 villages. (Gop.pk)

According to 1988 census report of Pakistan the area and population are divided in the four tehsils of district Muzaffar Garh as, 
Table 1

Area and Population by District/Tehsil According to 1998 Census

\begin{tabular}{|l|l|l|}
\hline District/ Tehsil & Area & $\begin{array}{l}\text { Census Population } \\
\text { (thousand persons) }\end{array}$ \\
\hline Muzaffar Garh (district) & 8249 & 2636 \\
\hline Alipur & 1391 & 398 \\
\hline Jatoi & 1010 & 447 \\
\hline Kot Addu & 3471 & 808 \\
\hline Muzaffar Garh & 2377 & 983 \\
\hline
\end{tabular}

Sources: For area: cartographic office, survey of Pakistan, Rawalpindi for population: population Census Organization, Statistic Division, GOP, Islamabad

\section{ii. Electoral Politics in Muzaffar Garh}

Muzaffar Garh may be backward in terms of progress but since the 1950s it has subjugated the politics of Punjab. Nawab Mushtaq Gurmani was one of those persons who familiarized Muzaffar Garh to national politics when he signed the Karachi Agreement 1949 that established the Line of Control (ceasefire line) separating the Kashmir region.

Apart from his posts as minister of Northern Areas and Chief Executive of Kashmir Affairs and the Governor of Punjab, he was also Pakistan's interior minister from 1951 to 1954. Nawab Mushtaq Gurmani worked for the development of friendly relations with Egypt and take out the fear of Egypt about Pakistan. Egypt ruled the Muslim world and after independence of Pakistan it had feared that Pakistan will claim as the leader of the Muslim world. Gurmani assured Egypt that for the development of Muslim ummah the friendly relations between Muslim countries are necessary. For Kashmir issue he appealed for help and cooperation of Arab League for the peaceful solution. (Somroo, 2006, p.63)

Senior political figure Nawabzada Nasrullah Khan belonged from Muzaffar Garh. He is called father of democracy because he was working tirelessly for the restoration of democracy just before his death. He was the chairman of Alliance for Restoration of Democracy (ARD) and the significance feature of his political career was the willingness for build alliance with opposition parties and he served against military rulers too. In Pakistani politics he has pivotal position due to his struggle for democracy. In 1960s he becomes the leader of Awami League during Ayub Khan Era and played important role in Pakistan Democratic Movement by his elections. On the issue of electoral corruption in 1977 elections with Zulfikar Ali Bhutto he headed opposition team. First time he joint hand with his erstwhile rival in 1980 against General Zia's military government and the act of opposing military he repeated in 1998. (Storyofpakistan, 5 Jan 2009)

Another prominent leader from the land of district Muzaffar Garh is Ghulam Mustafa Khar. He was the close collaborator of Zulfikar Ali Bhutto and also one of the founders of PPP. During the period of PPP in 1970s Muzaffar Garh was represented by Ghulam Mustafa Khar who served as Chief Minister and Governor of Punjab. After some political wilderness he rejoined Bhutto before 1977 elections but was imprisoned by General Zia. After an understanding with Zia's commander General Chishti he left country and his close friend Ghulam Mustafa Jatoi became the prime minister. With the support of PPP dissidents along with Jatoi he formed National People's Party (NPP) in 1980s after his fallen out by Benazir 
Bhutto.

The NPP was backed by army for lessened the influence of Bhutto family from Sind. Khar contest 1988 elections for several seats and won all seats. Before 1993 elections he re-joined PPP and become federal minister for water and power. He defeated 1997 elections and became unable to contest 2002 elections due to the condition of graduation. Due to his controversial statement regarding the deal between Musharraf and Benazir Bhutto he was removed from PPP in 2007. (herald.com)

Another political personality from Muzaffar Garh is Hinna Rabbani Khar, daughter of MNA Noor Rabbani Khar and niece of Ghulam Mustafa Khar. She contested elections in 2002 from the platform of PML-Q and as the member of National Assembly she held the post of minister of state for economic affairs. In 2007 she left PML-Q and joined PPP and won 2008 elections. She was elected as minister for economic affairs. When Shah Mehmood Qurashi resigned from foreign ministry she was given the charge and responsibility of Pakistan's foreign relations. (Dailytimes, 22 Feb 2014)

The above given paragraphs showed the important personalities of District Muzaffar Garh and remaining lines describe the whole political situation of past and recent elections who won, who lost in elections.

Since 1988 parliamentary politics recommenced in Pakistan, after the long break that was General Zia's dictatorship, the politics of Muzaffar Garh 's four tehsils has been controlled and ruled by the, the Nawab family, the Hinjras, Khars, the Dastis, , the Jatoi, the Qureshi and the Gopangs. There are five National Assembly and 11 provincial assembly seats from Muzaffar Garh.

Several new faces were introduced in 2002 elections because of the degree issue. Muzaffar Garh was represented by three female contestants at the national level and three male candidates. Those were Khalida Mohsin Qureshi (PPP NA-176), Hina Rabbani Khar (PML-Q NA-177), Tehmina Dasti (PML-Q reserved seat). Shahid Jameel Qureshi of PML-Q was won NA-178 and NA-179 by Syed Basit Sultan of the same party. The NA-180 was won by PPP's Qayyum Jatoi. In the 2008 elections, all NA and six PA seats were won by the PPP and the prominent personalities were become the part of Government including Hina Rabbani Khar and Jamshed Dasti.

\section{iii. Elections 2013 and Electoral Politics}

For 2013 elections Dr. Shabbir Qureshi was contesting on NA-176 as the PPP candidate but before few days of election he withdraw on the insist of Yousaf Raza Gillani and pressure from other members of PPP. The PPP award ticket to him on his father place but near elections they considered any other senior member of PPP Mian Amjad Abbas Qurashi. The father of Shabbir Qurashi, Mian Mohsin Ali Qureshi was active member of PPP in district Muzaffar Garh and he has been in a coma since 2009. The wife of Mian Mohsin Ali Qureshi, Mrs. Khalda Muhsin was also the member of National Assembly in 2002. PML-N field Sultan Mahmood Hinjra for competing NA-176 and candidate of PML-N won the seat.

Another contestant, Malik Ghulam Mustafa Khar who left PPP and now he was the candidate of Pakistan Muslim League-Functional, tried to become the joint candidate of PML-N and PML-F because he had fear about his victory as he gained in past because for a long time he was absent from his respective area and constituency. PML-N offered Khar NA-177 where PML-N has no worthy candidate but Khar refused to face his brother Malik Noor Rabbani Khar as PPP candidate.

Noor Rabbani Khar in NA-177, the father of Hina Rabbani Khar was the PPP candidate whereas the PML-N has preferred Khalid Gurmani, who was two time runner up to Hina Rabbani Khar in elections 2002 and 2008. In the meantime, former tehsil nazim Rafiq Khar has problems with PML-N and has decided to compete as an independent candidate. Jamshed Dasti who had left the PPP was also an independent candidate for this seat. He was recently condemned to a three-year jail term and to pay a fine of Rs5, 000 for holding fake degree. But 
he appealed and allowed for contesting 2013 election. Noor Rabbani Khar has decided that his daughter Hina will not run after Jamshed Dasti used unmannerly language against her. (Dawn 13 April 2014)

For NA-178 seat PML-N rejected the son of Nawabzada Nasrullah, Nawabzada Iftikhar who was the leader of PML-N he contest elections on the ticket of PPP after being rejected by the PML-N. Before, Sajid Naeem Qureshi, the brother of former state minister Shahid Jameel Qureshi, was a PPP candidate for this seat.

Jamshed Dasti was contesting polls here too as an independent candidate however the PML-N's choice was Sardar Ebad Dogar, who was a former Sipah-i-Sahaba leader. PPP candidates for NA-179 and NA-180, Moazzam Jatoi and Qayyum Jatoi were contesting but the choices of PML-N's were Haroon Sultan Bukhari and Abdullah Bukhari.

Former MNA of PML-Q Ashiq Gopang cleared before elections that he has not left the PML-Q and he is still contesting elections on the ticket of PML-Q not as an independent candidate. Another obstacle was waiting for PML-N in 2013 elections as the Bukharis PML-N's priority were dogged by dual nationality charges and summoned by the Election Commission of Pakistan.

In Muzaffar Garh politics PTI was also a new factor and PTI inject its members in the Area of Muzaffar Garh. Amongst its potential contestants was Nawab Mansoor Khan, former Punjab revenue minister and the son of Nawabzada Nasrullah Khan. He is contesting for the seat of NA-179 whereas for NA-180 there is another former MNA, Jameel Bukhari. (Dawn, 13 April 2014)

A succession of rulers from the same family or line is known as Dynastic politics. Dynastic politics, illiteracy and poverty tend to coexist. Dynastic politics is the strongest where political institutions are weak and personalities dominate and where political parties refuse to transform from family fiefdoms to genuine political institutions. In some way dynastic politics breed also with poverty or illiteracy. Dynastic politics remain dominant in politics of Pakistan and in District Muzaffar Garh as well. (Saleem, 2 Jan 2013) As the tree behind describe some renowned families captures the politics of Muzaffar Garh as, Khars, Hinjra, Qurashi, Bukhari, Gurmanis, Nawabzadas, and Dasti etc.

Table 2

Conduct of General Elections 2013 Number of Registered Voters/Polling Stations/Polling Booths

\begin{tabular}{|l|l|l|l|l|l|}
\hline \multirow{2}{*}{$\begin{array}{l}\text { Name of } \\
\text { Constituency }\end{array}$} & \multicolumn{3}{|l|}{$\begin{array}{l}\text { Total No of Registered } \\
\text { Voters }\end{array}$} & Polling Stations & Polling Booths \\
\hline & Male & Female & Total & & \\
\hline NA-176 & 186848 & 151389 & 338237 & 304 & 700 \\
\hline NA-177 & 189991 & 167962 & 357953 & 306 & 703 \\
\hline NA-178 & 187678 & 161968 & 349646 & 302 & 735 \\
\hline NA-179 & 183233 & 157141 & 340374 & 292 & 640 \\
\hline NA-180 & 163330 & 132836 & 266166 & 262 & 595 \\
\hline
\end{tabular}


Source: http://ecp.gov.pk/Misc/stats/punjab/pp\%stations.pdf

The above given table mentioned the five constituencies of National Assembly for district Muzaffar Garh, total registered voters with male and female numbers and polling stations and polling booths for 2013 elections. The population was in thousands in each constituency but the numbers of polling stations and booths were in hundreds.

Table 3

Constituency wise Result of Muzaffar Garh in National Assembly Elections 2013

\begin{tabular}{|l|l|l|l|l|}
\hline Constituency & Winning Candidates & $\begin{array}{l}\text { Political } \\
\text { Party }\end{array}$ & $\begin{array}{l}\text { \# of Votes } \\
\text { taken }\end{array}$ & $\begin{array}{l}\text { \% of total } \\
\text { Registered Votes }\end{array}$ \\
\hline NA-176 & $\begin{array}{l}\text { Malik } \\
\text { MehmoodHinjra }\end{array}$ & PML-N & 88,322 & $26.11 \%$ \\
\hline NA-177 & Jamshaid Ahmad Dasti & IND & 103,327 & $28.87 \%$ \\
\hline NA-178 & $\begin{array}{l}\text { Jamshaid Ahmad Dasti } \\
\text { NA-179 }\end{array}$ & $\begin{array}{l}\text { IND } \\
\text { Sultan }\end{array}$ & 79,417 & $22.71 \%$ \\
\hline NA-180 & $\begin{array}{l}\text { Ashiq Hussain Khan } \\
\text { Gopang }\end{array}$ & IND & 72,044 & $24.33 \%$ \\
\hline
\end{tabular}

Sources: $\quad$ 1- http://ecp.gov.pk/Misc/Stats/Punjab/NA\%20STATION.pdf

2-

http://www.ecp.gov.pk/electionresult/AllResults.aspx?assemblyid=NA

The table indicates the complete National Assembly result, with the names of winning candidates, their respective political party and number of vote taken. From N.A's five seats two winning candidates were belongs to PML-N and three independent candidates won the elections. Malik Sultan Mehmood Hinjra of PML-N captured N.A176, Jamshaid Dasti won N.A 177 and 178 as independent candidate, Sayed Basit Sultan got NA-179 and Ashiq Gopang captured NA-180. 
Table 4

Punjab Provincial Assembly Results of Elections 2013

\begin{tabular}{|c|c|c|c|c|c|c|}
\hline $\begin{array}{l}\text { Constituenc } \\
\mathbf{y}\end{array}$ & $\begin{array}{l}\text { Winning } \\
\text { Candidates }\end{array}$ & $\begin{array}{l}\text { Political } \\
\text { Party }\end{array}$ & $\begin{array}{l}\text { \# of Votes } \\
\text { taken }\end{array}$ & $\begin{array}{l}\% \text { of total } \\
\text { Registered } \\
\text { Votes }\end{array}$ & Male & Female \\
\hline PP-251 & Ahmad Yarhinjra & PML-N & 32905 & $20.47 \%$ & 86310 & 74462 \\
\hline PP-252 & $\begin{array}{l}\text { Muhammad } \\
\text { ZeshanGurmani }\end{array}$ & IND & 20400 & $11.50 \%$ & 94215 & 83171 \\
\hline PP-253 & $\begin{array}{l}\text { GhulamMurtaza } \\
\text { Raheem }\end{array}$ & IND & 34988 & $23.92 \%$ & 83783 & 62517 \\
\hline PP-254 & $\begin{array}{l}\text { Hammad Nawaz } \\
\text { Khan Tipu }\end{array}$ & PML-N & & & 91401 & 78526 \\
\hline PP-255 & $\begin{array}{l}\text { MianAlamdar } \\
\text { Abbas Qurashi }\end{array}$ & IND & 47255 & $29.53 \%$ & 84857 & 75153 \\
\hline PP-256 & $\begin{array}{l}\text { Muhammad } \\
\text { Imran }\end{array}$ & PML-N & $\begin{array}{l}30 \\
06 \\
1\end{array}$ & $19.38 \%$ & 83213 & 71895 \\
\hline PP-257 & $\begin{array}{l}\text { Ahmad Karim } \\
\text { Qaswar Langrial }\end{array}$ & PML-N & 33080 & $22,97 \%$ & 78290 & 65697 \\
\hline PP-258 & $\begin{array}{l}\text { SayedHaroon } \\
\text { Ahmad Sultan } \\
\text { Bukhari }\end{array}$ & PML-N & 46189 & $31.85 \%$ & 78142 & 66900 \\
\hline PP-259 & $\begin{array}{l}\text { Sardar Khan } \\
\text { Muhammad } \\
\text { Khan Jatoi }\end{array}$ & PML-N & 45731 & $29.61 \%$ & 81981 & 72471 \\
\hline PP-260 & $\begin{array}{l}\text { Muhammad } \\
\text { SibtainRaza }\end{array}$ & IND & 29491 & $21.16 \%$ & 76759 & 62609 \\
\hline PP-261 & AamirTalal Khan & IND & 40967 & $31.51 \%$ & 72129 & 57895 \\
\hline Total & & & & & 911080 & 771296 \\
\hline
\end{tabular}

Source: http://www.ecp.gov.pk/electionresult/AllResults.aspx?assemblyid=PP

Table showed the results of Provincial Assembly results of 2013 elections of 11 constituencies of district Muzaffar Garh. Six seats out of eleven were captured by the candidates of PML-N. PML-N dominates the provincial assembly seats and remaining seats were captured by independents candidates. PPP-P lost all seats in the respective area.

To analyze the electoral politics in Muzaffar Garh researchers has designed a questionnaire 
for respondents of district Muzaffar Garh. The questionnaire consisted of multiple choice questions and yes/no questions. The results of the questionnaire filled by the selected population of different constituencies of Muzaffar Garh show that the majority of people in district Muzaffar Garh interested in elections and electoral politics. They participated in elections by attending processions, public meetings and party membership and most important by casting their votes.

The questionnaire included the some basic questions like age, sex, qualification of respondents and specific questions related to elections and electoral politics of district Muzaffar Garh such as, interest in politics, which party describe you the best, vote cast in previous elections, decision of voting and influence on voting decision, preference of party for vote casting, roll of political parties for the education of voters and best source to educate them, impact of electronic media on election results, party's manifestoes are good for public and demand of change in manifestoes according to time, roll of electoral candidates before and after the elections, political development through elections and best system for Pakistan, change in country through elections, permission to female members to cast vote on their own choice, vote cast in 2013 elections, highly positive voter turnout in 2013 elections, free and fair 2013 elections, most important political issue for new government and one question especially asked about PTI the third largest rising party in 2013 elections.

i) Age, gender and qualification of Respondents

The survey through questionnaire was conducted for analyzing electoral politics at micro level in District Muzaffar Garh. For the measurement of views the data was collected from the different age group persons, five categories were made. $30.7 \%$ are of the age of $18-22$, $20.7 \%$ are of the age of $23-27,17.3 \%$ are from the age of $28-32,20.7 \%$ are of the age of 33-37, whereas $10.7 \%$ are from above 37 . So the maximum data was collected from the 18-22. $64 \%$ male and $35 \%$ female respondents participated in the survey. Five categories were made for respondents as $6 \%$ were primary educated, $8.7 \%$ were middle, $15 \%$ were secondary, $40 \%$ have higher secondary education and $30 \%$ people were above higher secondary education.

\section{ii) Interest in politics}

To measure the views of people about their interest in politics the data was collected from the targeted population. Data showed that $30.7 \%$ have great interest in politics, $38 \%$ have some interest whereas $31.3 \%$ remain neutral on politics in district Muzaffar Garh.

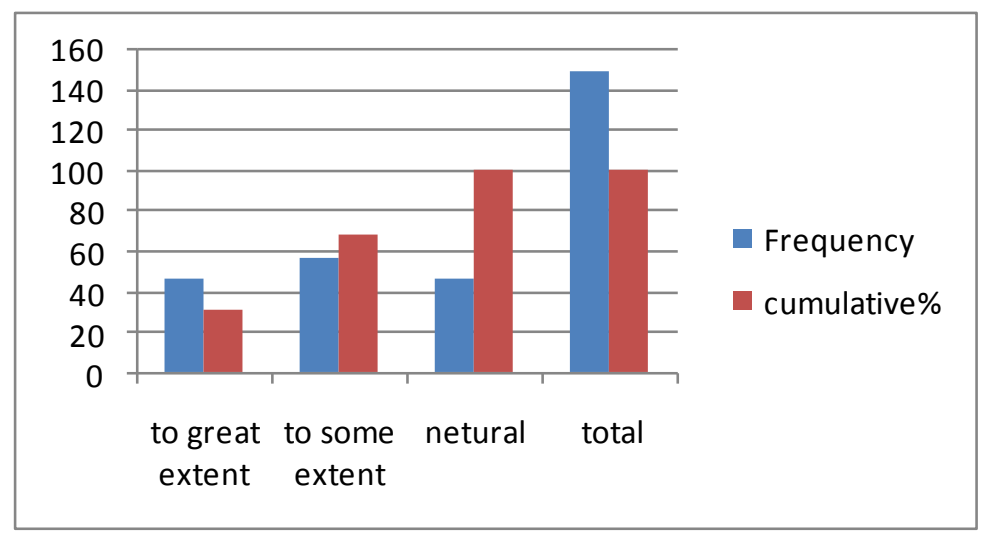

iii) Views about the nature of political party.

Collected data showed people prefer national parties in spite of ethnic and regional parties. In 


\section{Macrothink}

district Muzaffar Garh there are two parties dominating PPP and PML-N but in 2013 PTI also emerged as third party in Muzaffar Garh like other parts of Pakistan although its candidates were not succeeded. People are interested in politics as $87 \%$ people casted their votes in the

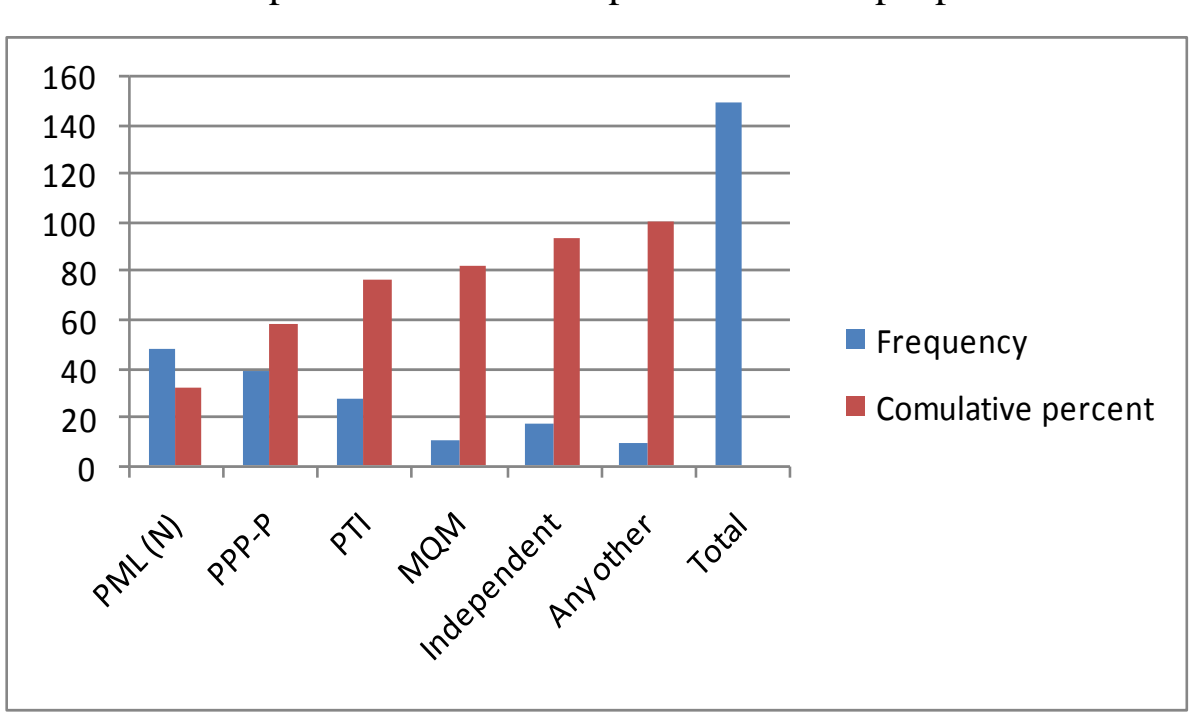

elections.

iv) Voting decision and influence on decision

Respondent answered the statement about when they make their voting decision $84 \%$ people said they decide before elections and 245 said they decide on polling day. $42 \%$ people said they have Biradri/family influence on their voting decision, $22.7 \%$ voted for party manifestoes and $35 \%$ preferred national interest.
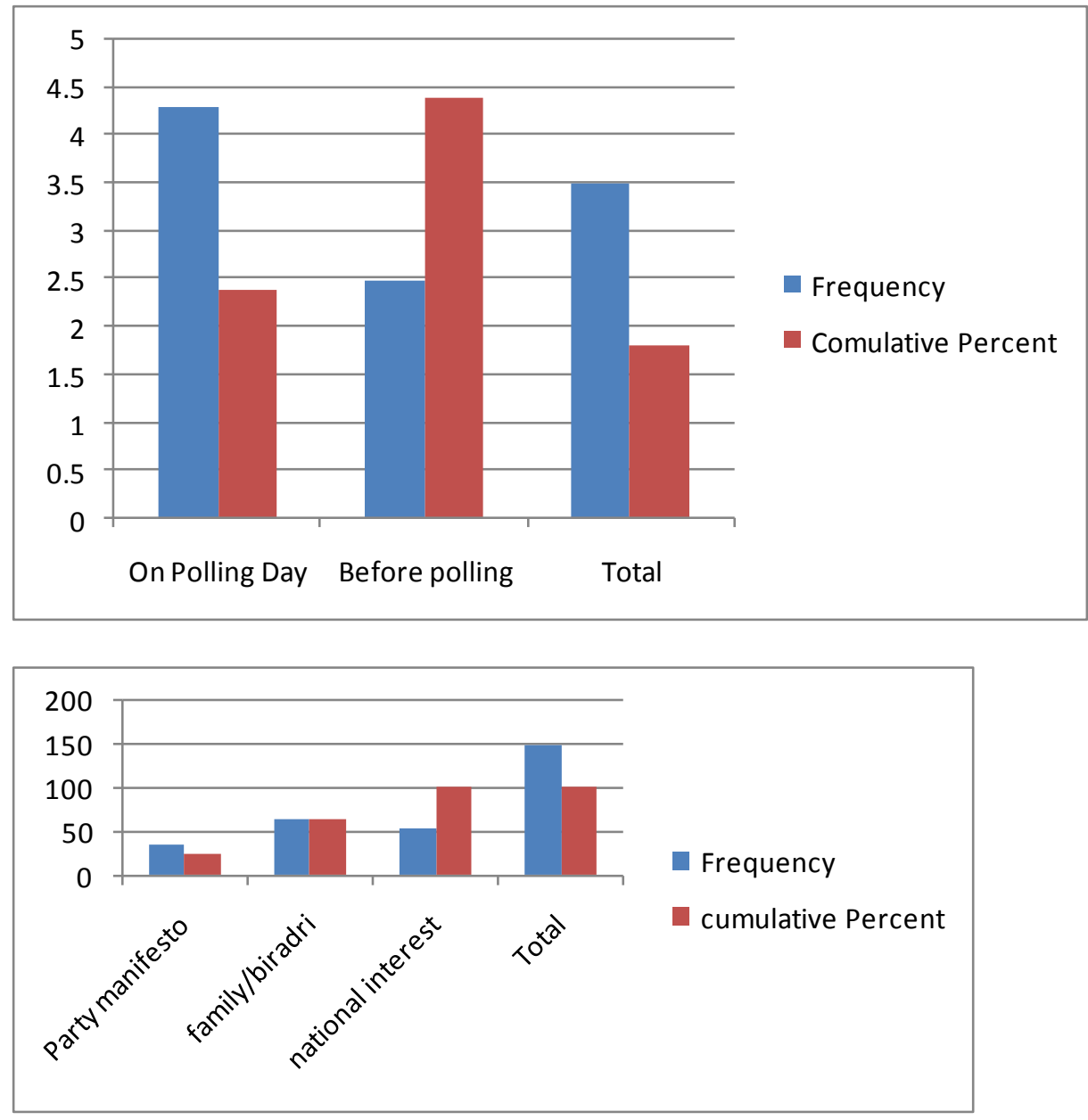
v) Statements related political parties

The analyzed data showed the result that political parties created political awareness in public through media campaign, party memberships, public meetings, and by processions. 50\% people preferred awareness through media and accepted that it has positive impact on elections results. 56\% respondents of district Muzaffar Garh are satisfied with the role of political parties but $43 \%$ denied the statement.

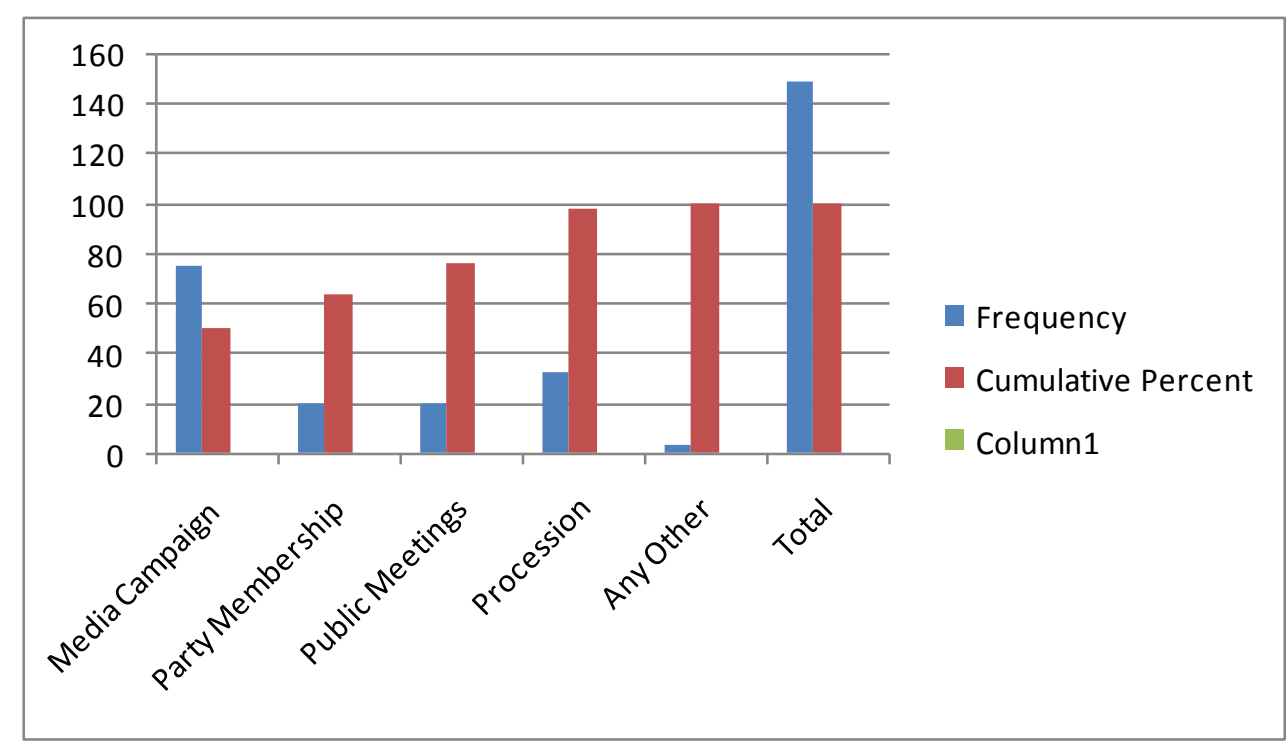

vi) Statements regarding manifestoes

$70 \%$ people among the targeted population said political part's manifestoes are good for public and $29 \%$ said no. actually in counterparts of Pakistan people cast their vote to those parties whose policies are best for public interest but unfortunately people are not fully aware with the importance of party's manifestoes. When respondent have asked parties change their manifestoes according to the needs of time $81 \%$ people said yes but $18.7 \%$ people have knowledge about it and they said no.

vii) Behavior of electoral candidates before/after elections

According to analyzed data $54 \%$ respondents said their respective candidates expose the problems of the area but $46 \%$ people were against it. The $66.7 \%$ people are in favor of the statement that electoral candidates of their areas provide an access before elections but after elections selected candidates never provide access to the people of the areas and 54\% people were favored in the statement. $9.3 \%$ people said yes every time. 

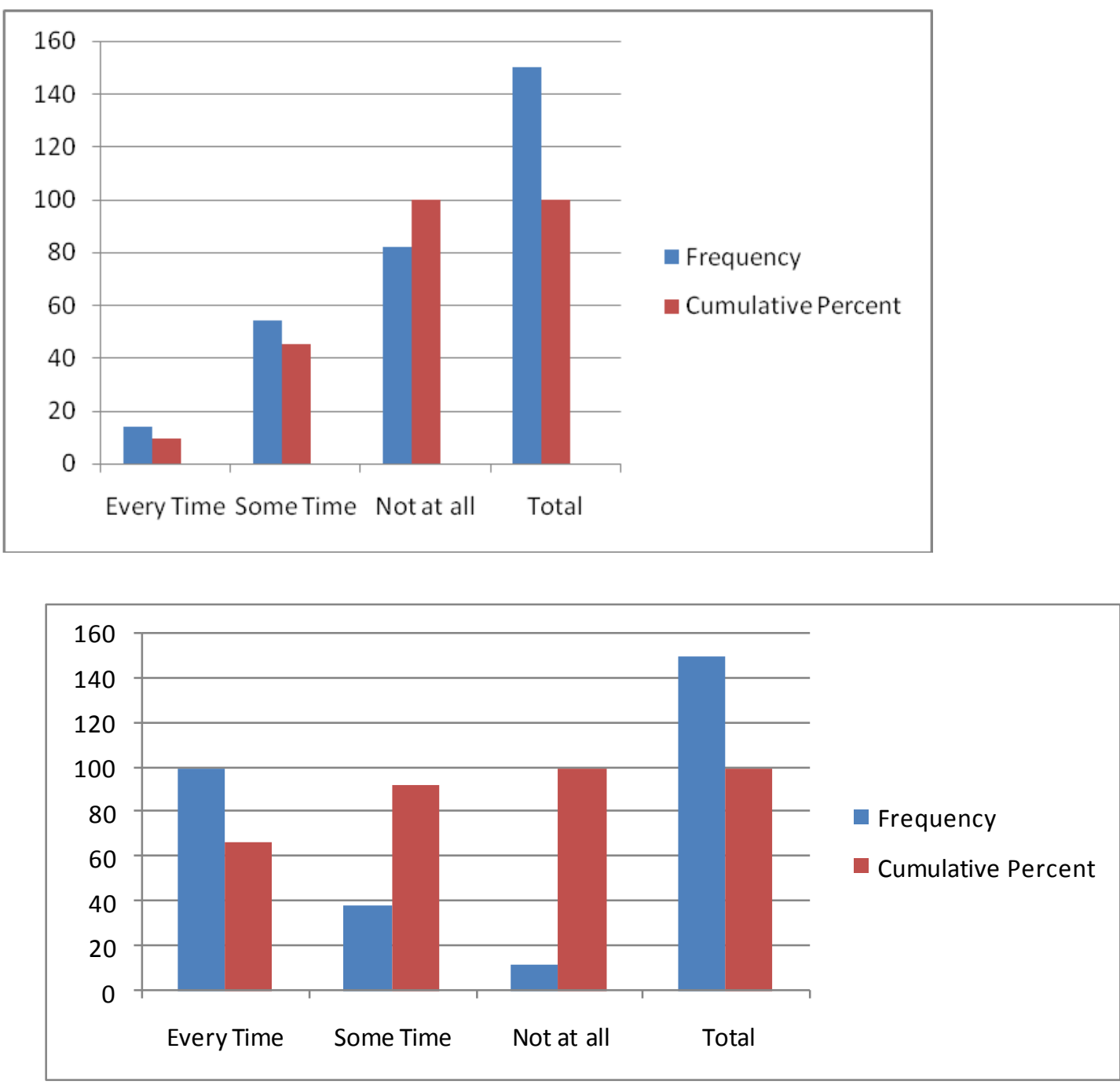

viii) Political development/suitable system for Pakistan

To measure the views of people about that political development is possible through elections, $84.7 \%$ participants are agreed and $15.3 \%$ are disagreed from the statement. According to the opinion of $82 \%$ people democratic system is best for Pakistan and $13.3 \%$ people voted for authoritative system. The $87 \%$ targeted population said election can bring change in country but $12.7 \%$ said elections cannot bring change in country.

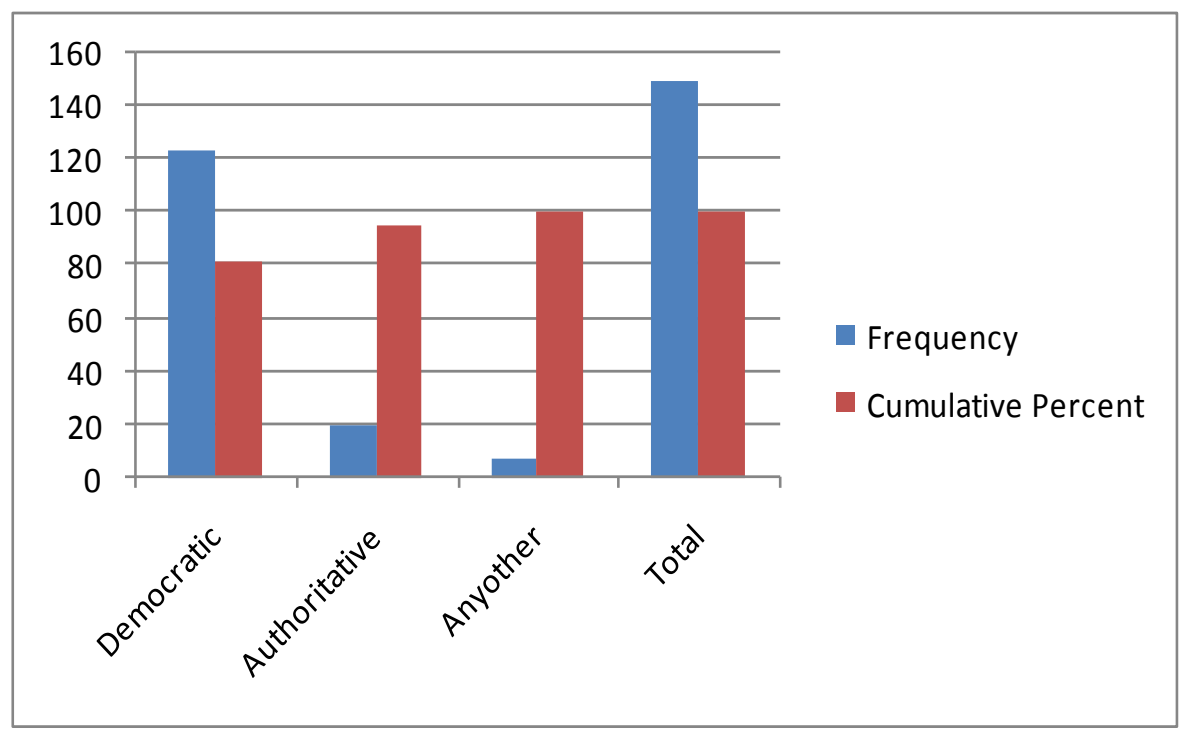


ix) Participation of women

The collected data indicates that $93 \%$ people of district Muzaffar Garh allowed their female members to go for vote cast and $71 \%$ people allowed their females to cast their vote on their own choice. On the other hand $6.7 \%$ people never allowed their women to go out for vote and $28.7 \%$ male/families never allowed their women to cast their vote on their own choice.
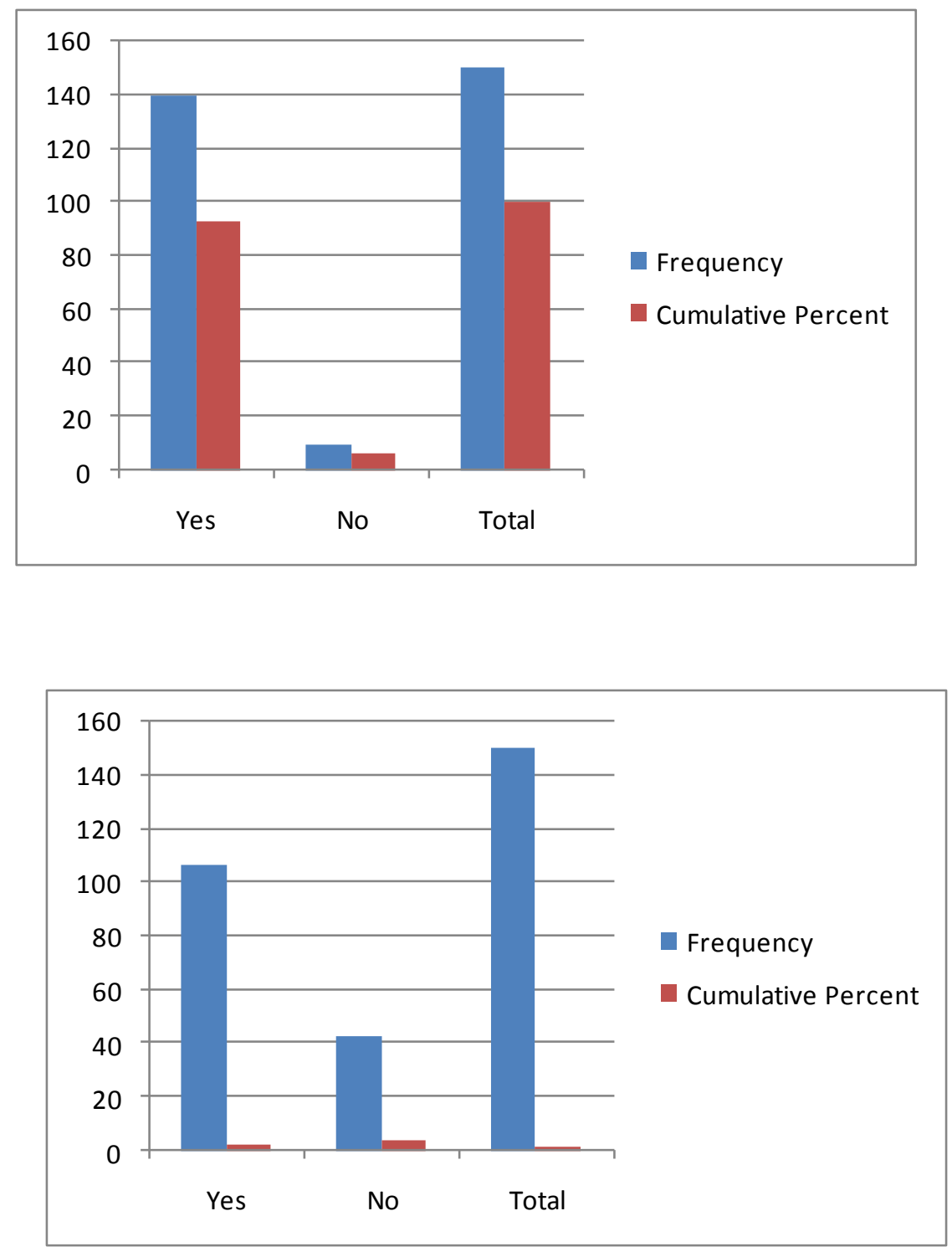

x) Participation in 2013 elections

$78 \%$ respondents used their right of vote in 2013 elections whereas $22 \%$ people did not cast their vote. 


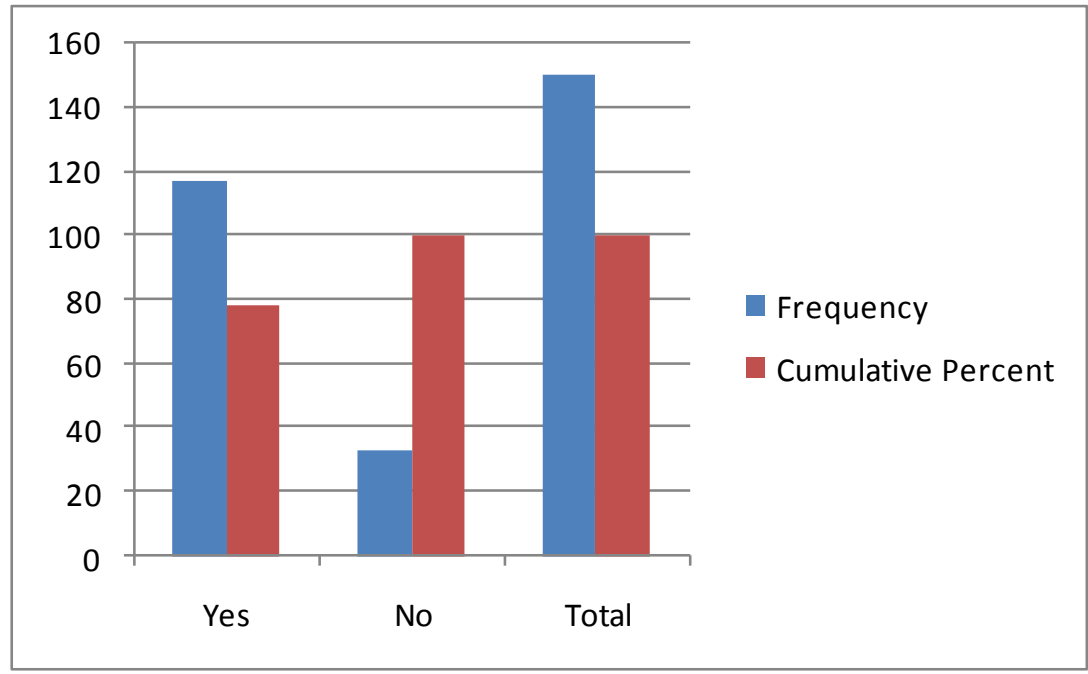

xi) Voter turnout/free and fair elections

The respondents are agreed that voter turnout in 2013 elections was highly positive in comparison to previous elections. 50\% respondents were in favor of the statement that 2013 elections were free and fair due to active and vibrant media. But $50 \%$ were not sure about it.

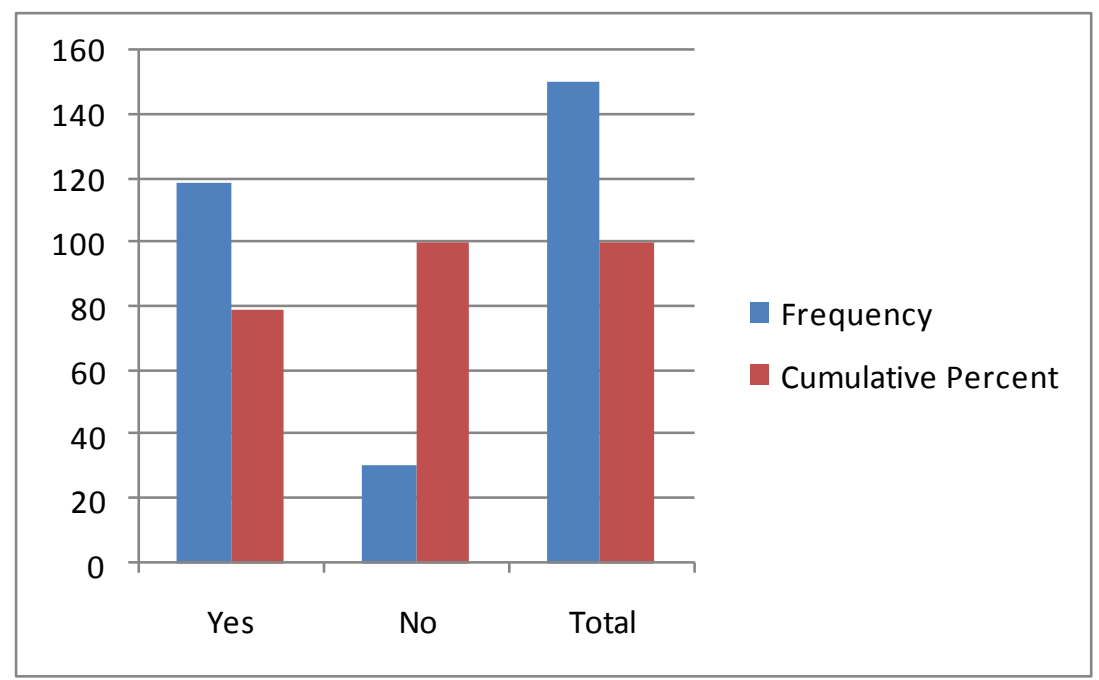

xii) greater participation of women and youth

To measure the views of targeted population for data collection in answer to the statement do you agree youth participation was greater than before in election 2013. According to $89.3 \%$ respondents yes the youth participation was greater than before and $10.7 \%$ said youth participation was not greater. Like youth participation of women participation was also high positive as $81 \%$ people favored the statement but $18.7 \%$ were opposed it. 
Women Participation

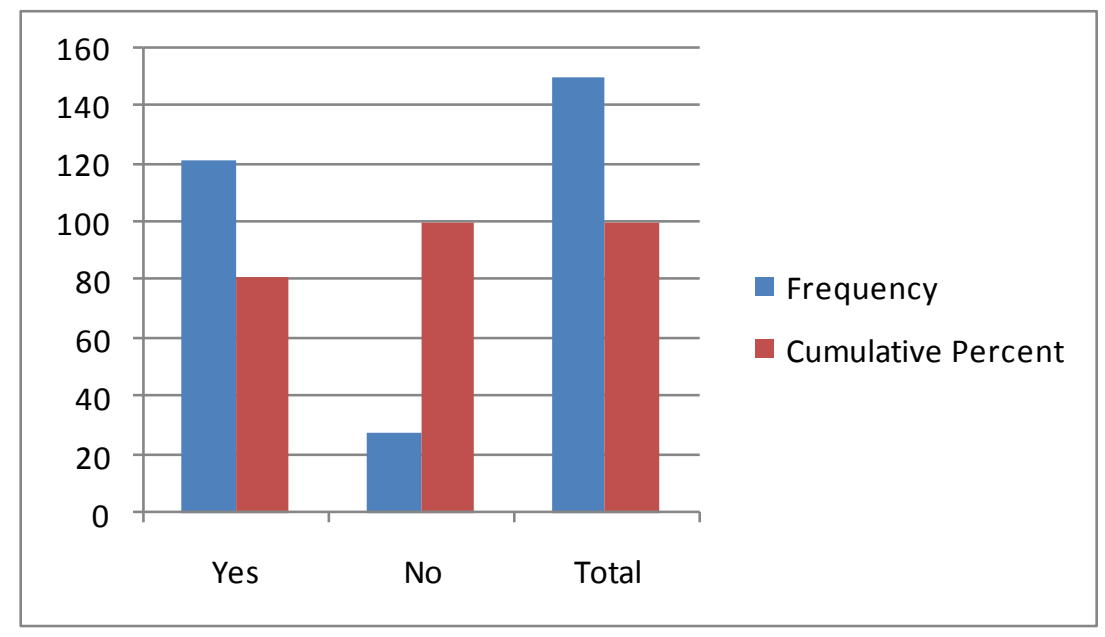

Youth Participation

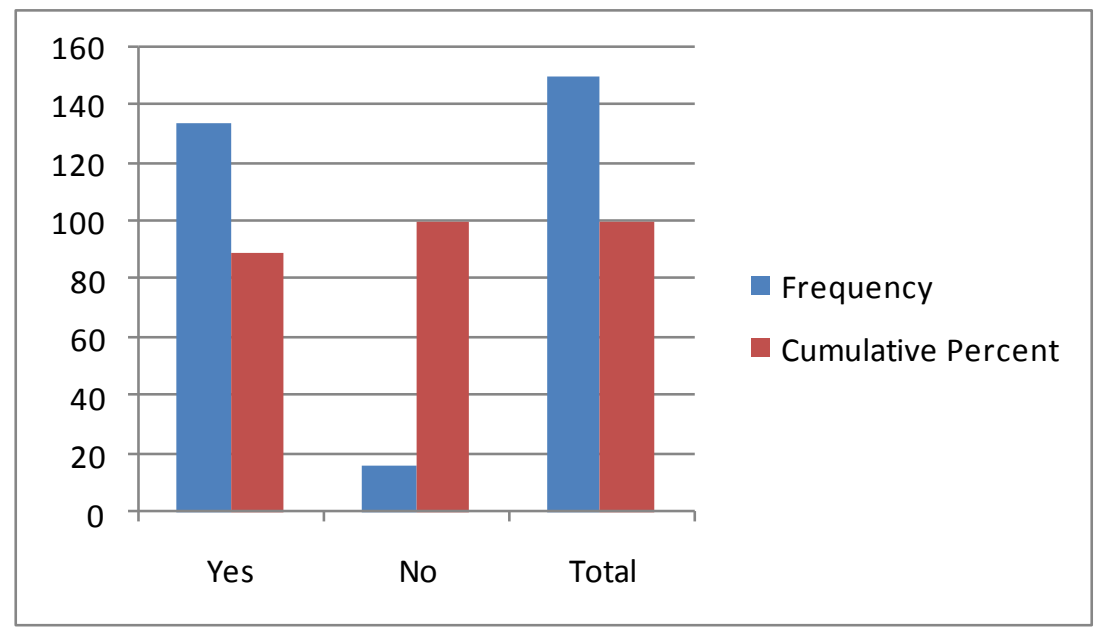

xiii) PTI is really a game changer

Participants in answer to the statement do you believe PTI is really a game changer in the history of Pakistan. The question was asked because in election 2013 PTI emerged as third largest party. The result shows $36 \%$ people favored the statement and 64\% against the statement.

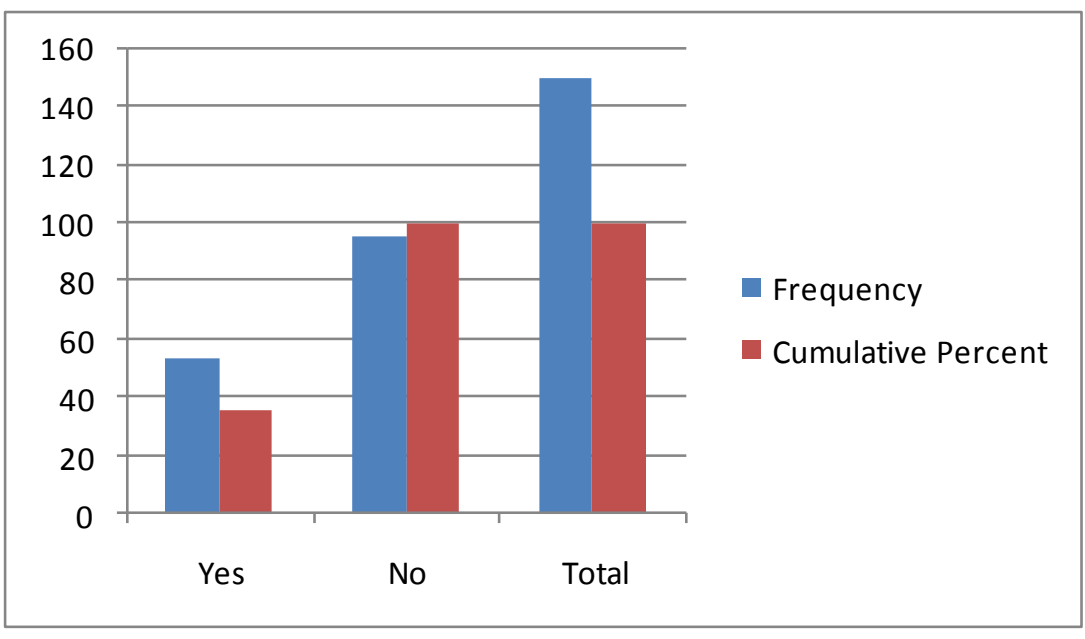


xiv) Most important political issue for new government

Table indicates the calculated value of the collected data from the participants in answer to the most important political issue for new government. 57.3\% respondent preferred security problem, $28.7 \%$ in favor of energy crisis and $14 \%$ people said corruption should be the first priority of government.

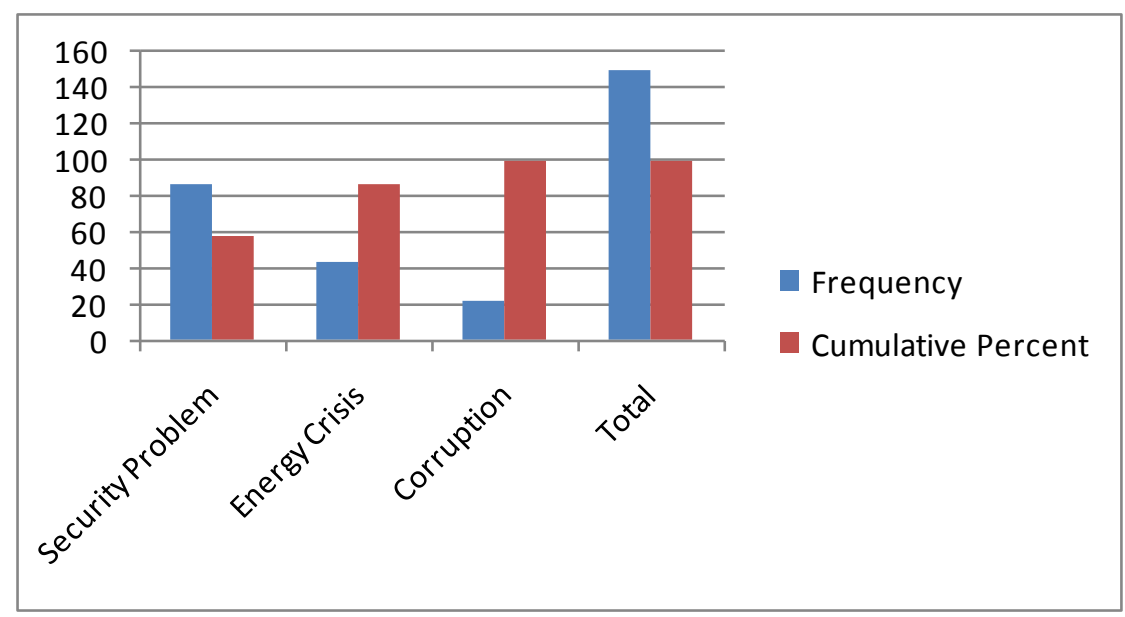

\section{Conclusion}

A questionnaire has been designed for the respondents of Dist. Muzaffar Garh.The questionnaire consisted of multiple choice questions and yes/no questions. The result of the questionnaire filled by the selected population of different constituencies of Muzaffar Garh show that the majority of people in district Muzaffar Garh interested in electoral politics. They participate in elections by attending processions, by public meetings and by party membership and most important by casting their vote. The data was collected from the different age group persons, five categories were made. $30.7 \%$ are of the age of $18-22,20.7 \%$ are of the age of $23-27,17.3 \%$ are from the age of $28-32,20.7 \%$ are of the age of $33-37$, whereas $10.7 \%$ are from above 37 . So the maximum data was collected from the $18-22$ age groups in the perspective of 2013 election.

$30.7 \%$ have great interest in politics, 38\% have some interest whereas $31.3 \%$ remain neutral on politics in district Muzaffar Garh. People make their voting decision $84 \%$ people said they decide before elections and 245 said they decide on polling day. $42 \%$ people said they have Biradri/family influence on their voting decision, $22.7 \%$ voted for party manifestoes and $35 \%$ preferred national interest. The analyzed data showed the result that political parties create political awareness in public through media campaign, party memberships, public meetings, and by processions. 50\% people preferred awareness through media and accepted that it has positive impact on elections results. 56\% respondents of district Muzaffar Garh are satisfied with the role of political parties but $43 \%$ denied the statement. $70 \%$ people among the targeted population said political part's manifestoes are good for public and $29 \%$ said no and when respondent have asked parties change their manifestoes according to the needs of time $81 \%$ people said yes but $18.7 \%$ people have knowledge about it and they said no.

According to analyzed data $54 \%$ respondents said their respective candidates expose the problems of their area but $46 \%$ people were against it. $84.7 \%$ participants believe political development is possible through elections and $15.3 \%$ are disagreeing. According to the opinion of $82 \%$ people democratic system is best for Pakistan and $13.3 \%$ people voted for 
authoritative system. The $87 \%$ targeted population said election can bring change in country but $12.7 \%$ said elections cannot bring change in country. The collected data indicate that $93 \%$ people of district Muzaffar Garh allowed their female members to go for vote cast and $71 \%$ people allowed their females to cast their vote on their own choice. On the other hand $6.7 \%$ people never allowed their women to go out for vote and $28.7 \%$ male/families never allowed their women to cast their vote on their own choice. $78 \%$ respondents use their right of vote in 2013 elections whereas $22 \%$ people did not cast their vote.

The respondents are agreed that voter turnout in 2013 elections was highly positive in compare to previous elections. 50\% respondents were in favor of the statement that 2013 elections were free and fair due to active and vibrant media. But 50\% were not sure about it. According to $89.3 \%$ respondent's yes the youth participation is greater than before and $10.7 \%$ said youth participation is not greater. Like youth participation women participation was also high positive as $81 \%$ people favored the statement but $18.7 \%$ were opposed it. The participants answered that the most important political issue for new government. $57.3 \%$ respondent preferred security problem, $28.7 \%$ in favor of energy crisis and $14 \%$ people said corruption should be the first priority of government.

Through questionnaire we find that electoral system in Pakistan has many problems not only on macro level but on micro level too such as in Muzaffar Garh district. People have no facilities on polling stations especially for disable and seniors citizens. Due to lack of proper facilities at polling booths voters hesitate to come for casting vote and this is the main reason of less voter turnout in country. In less developed areas like Muzaffar Garh people have pressure from biradri, from feudal lords, from landlords and sometime political parties pressurized the people and try to steal the mandate of other political party or group.

The behavior of party leaders also matter as candidates before elections provides easy access to voters but after selecting for National and Provincial assemblies they could not like to meet people. Electoral rigging is common in Pakistan as registration of voters in more than one constituency is one of the kinds of electoral rigging. Manual counting is a big drawback of Pakistani electoral system. On the pressure of some powerful party the election staff can easily change the result and manipulate the mandate of nation. Because of such reasons peoples of Pakistan are fed up from politics instead of going for casting votes thy feel better to stay at home.

Election Commission of Pakistan should reform political and electoral system of Pakistan and should take certain steps to increase voter turnout. First of all ECP should introduced online voting system or electronic system for voter registration, vote casting and vote counting and to reduce the election fraud and promote accurate results. ECP should make responsible political parties to hold elections within part twice a year so that honest people hold the party. Political parties should played their role for the political socialization of people and arranged time to time public meetings and seminars etc. government should make policies for provide education and equal rights to people so that to reduce the power of biradrism, landlords and feudal lords.

\section{References}

1. Election, Encyclopedia Britannica Online. Retrieved 18 August 2009

2. Sills, David L. (1968). International Encyclopedia of the Social Sciences: New York, the Macmillan Company \& Free Press.

3. Ahmed, M. (2004).Faisalabad Division ke Siasat per Biradarism kay Asraat, Ph. D Thesis, Department of Political Science and International Relations, Multan, B. Z. University.

4. National Assembly Elections in Pakistan 1970- 2008: A Compendium of election related facts Church World Service- Pakistan/ Afghanistan/FAFEN, 2012 
5. Desai, Meghna \& Ahsan, Aitzaz. (2005). Cross-border Talks: Divided by Democracy, New Delhi: Roli Books

6. Mujahid, Al. Sharif. (1971). Pakistan: First General Elections, Asian Survey, and Vol.11

7. Daily Times, Hashmi, Kamran Sayed, 'Election 2013 and The Failure of Political Analysts', Friday, May17, 2013

8. 1998 District Census Report of Muzaffar Garh.(September 2000). Publication No.120, Population Census Organization Statistics Division, Government of Pakistan: Islamabad

9. District Muzaffar Garh Profile, Whole Schools Improvement Program (WSIP), 2013,Dubai Cares: Idara-e-Taleem-o-Aagahi(ITA)

10. for area: cartographic office, survey of Pakistan, Rawalpindi

11. For population: population Census Organization, Statistic Division, GOP, Islamabad

12. Soomro, Pir Buksh.(2006). "Nawab Mushtaq Ahmad Gurmani's Role in Politics of Pakistan"Pakistan Journal of Historya7 Culture, Vol.xxvii/2

13. www.storyofpakistan.com

14. www.herald.com

15. Daily Times, 22 Feb 2014

16. Dawn News, 13 April 2014

17. The News, "Dynastic Politics" by Farrukh saleem, 2 January 2013

18. . http://ecp.gov.pk/Misc/stats/punjab/pp\%stations.pdf

19. http://ecp.gov.pk/Misc/Stats/Punjab/NA\%20STATION.pdf

20. http://www.ecp.gov.pk/electionresult/AllResults.aspx?assemblyid=NA 